\title{
Écritures du Burkina Faso, a cura di Marie-Ange Somdah
}

Ilaria Vitali

\section{(2) OpenEdition}

1 Journals

\section{Edizione digitale}

URL: http://journals.openedition.org/studifrancesi/33893

DOI: 10.4000/studifrancesi.33893

ISSN: 2421-5856

\section{Editore}

Rosenberg \& Sellier

\section{Edizione cartacea}

Data di pubblicazione: 1 décembre 2005

Paginazione: 693

ISSN: 0039-2944

\section{Notizia bibliografica digitale}

Ilaria Vitali, «Écritures du Burkina Faso, a cura di Marie-Ange Somdah», Studi Francesi [Online], 147 (XLX)

III) | 2005, online dal 30 novembre 2015, consultato il 19 avril 2021. URL: http://

journals.openedition.org/studifrancesi/33893 ; DOI: https://doi.org/10.4000/studifrancesi.33893

Questo documento è stato generato automaticamente il 19 avril 2021.

\section{(c) (i) (9)}

Studi Francesi è distribuita con Licenza Creative Commons Attribuzione - Non commerciale - Non opere derivate 4.0 Internazionale. 


\title{
Écritures du Burkina Faso, a cura di Marie-Ange Somdah
}

\author{
Ilaria Vitali
}

NOTIZIA

Écritures du Burkina Faso, a cura di Marie-Ange somDAH, Paris, L'Harmattan, 2003, pp. 169.

1 Dopo un lungo periodo di stasi, la letteratura francofona del Burkina Faso sembra essere divenuta oggi uno spazio fecondo che conta, ogni anno, la pubblicazione di diversi titoli appartenenti ai generi più diversi. Grazie alla creazione di strutture atte alla promozione e diffusione del libro, nuovi autori di talento si vanno progressivamente affermando. L'ultima sezione, dall'eloquente titolo La «Bibliothèque du Faso», è una bibliografia dettagliata che riflette le ultime ricerche, offrendo così linee guida e spunti di ricerca a chi volesse avvicinarsi allo studio di questa giovane letteratura. Sette contributi di specialisti, che spaziano dal teatro, alla poesia, al romanzo, fondamentali per accostarsi ad una letteratura ancora poco conosciuta. 